\title{
Wskazania homiletyczne zawarte w Listach o wymowie ojca Euzebiusza Statecznego
}

Historia kaznodziejstwa, w której ramach mieści się niniejsza refleksja, utrwala i przekazuje kolejnym pokoleniom pamięć nie tylko o głosicielach słowa Bożego. Swoje zainteresowanie koncentruje także wokół twórców teorii kaznodziejstwa. Dzięki opracowanym przez nich praktycznym wskazaniom kaznodzieje mogą doskonalić swój warsztat. Podręczniki historii kaznodziejstwa, choćby te, które w ostatnich latach opracował ks. prof. Kazimierz Panuś2, przywołują wiele nazwisk praktyków i teoretyków głoszenia słowa Bożego. Istnieją jednak twórcy mniej znani, których dorobek nie został dostrzeżony i utrwalony. Nie znaczy to jednak, że ich dzieła nie zasługują na uwagę i analizę. Do grupy mało znanych teoretyków kaznodziejstwa przełomu XIX i XX wieku należy zaliczyć o. Euzebiusza Franciszka Statecznego OFM, który wszedł do ich gro-

1 Jarosław Włodarczyk OFM - doktorant w Katedrze Komunikacji Religijnej Wydziału Teologicznego Uniwersytetu Papieskiego Jana Pawła II w Krakowie, sekretarz ewangelizacji w bernardyńskiej prowincji Zakonu Braci Mniejszych, redaktor czasopisma sanktuarium w Kalwarii Zebrzydowskiej „Pielgrzym Kalwaryjski”. Mieszka w Krakowie.

2 Zarys historii kaznodziejstwa w Kościele katolickim, cz. 1: Kaznodziejstwo w Kościele powszechnym, Kraków 1999; Zarys historii kaznodziejstwa w Kościele katolickim, cz. 2: Kaznodziejstwo w Polsce, t. 1: Od średniowiecza do baroku, t. 2: Od Oświecenia do XX wieku, Kraków 2001. 
na dzięki opracowanym przez siebie Listom o wymowie. Celem niniejszego artykułu jest przypomnienie postaci o. Statecznego, dokonanie analizy treści jego dzieła, a także znalezienie odpowiedzi na pytanie, na ile jego wskazówki dla mówców są dziś aktualne.

\section{Sylwetka i spuścizna literacka ojca Euzebiusza Franciszka Statecznego}

Franciszek Stateczny ${ }^{3}$ urodził się 1 października 1864 roku w Witosławicach koło Koźla. Był synem Józefa i Pauliny z domu Kirchniawa4 . Wykształcenie zdobywał najpierw przez trzy lata w niemieckiej szkole ludowej w Grzędzinie.

3 Ważniejsze prace o Euzebiuszu Franciszku Statecznym: A. J. Szteinke, Euzebiusz Franciszek Stateczny OFM (1864-1921) w świetle nowych źródet, „Studia Franciszkańskie” 16 (2006), s. 283-311; K. Biliński, Modernista w habicie. Ksiądz Franciszek Euzebiusz Stateczny oraz jego pamiętnik, Wrocław 1998; B. J. Mazurkiewicz, Aspekty pastoralne w twórczości kaznodziejskiej i publicystycznej o. Euzebiusza F. Statecznego OFM (1864-1921), praca doktorska z homiletyki napisana w Instytucie Teologii Pastoralnej przy Wydziale Teologicznym KUL pod kierunkiem ks. prof. dr. hab. Józefa Kudasiewicza, Lublin 1993, mps; K. Biliński, Nieznany pamiętnik ks. Euzebiusza Franciszka Statecznego na tle innych jego rękopisów, „Zaranie Śląskie” (1989) 2, s. 211-233; K. Biliński, Uwagi o życiu i twórczości ks. Franciszka Statecznego, „Annales Silesiae” (1989) 19, s. 33-49; M. Fazan, Stateczny Franciszek Euzebiusz, [w:] Śląski słownik biograficzny, t. 2, red. J. Kantyka i W. Zieliński, Katowice 1979, s. 233-237; A. Gładysz, Młoda Polska na Śląsku 1898-1922, Wrocław 1969, s. 15-40; S. Helsztyński, Meteory Młodej Polski, Kraków 1968, s. 63-86; Z. Hierowski, Życieliterackie na Ślasku 1922-1939, Katowice 1968; J. Kudera, Uwagi i myśli o rożnych, Biblioteka Śląska w Katowicach, Dział Zbiorów Specjalnych, sygn. R 106/1; W. Ogrodziński, O. Euzebiusz Franciszek Stateczny przedstawiciel „Młodej Polski” w prozie górnoślaskiej, „Rocznik Towarzystwa Przyjaciół Nauk na Śląsku" (1938) 6, s. 7-202; W. Ogrodziński, Dzieje piśmiennictwa śląskiego, Katowice 1965, s. 269275, 392-393; S. Smak, F. E. Stateczny (1864-1921), [w:] Pisarze śląscy XIX i XX w., red. Z. Hierowski, Wrocław 1963, s. 349-370; H. E. Wyczawski, Stateczny Euzebiusz Franciszek, [w:] Słownik polskich pisarzy franciszkańskich, red. H. E. Wyczawski, Warszawa 1981, s. 457-463.

${ }_{4}$ Bratem matki o. Statecznego był ks. Franciszek Kirchniawy (1843-1911), publicysta, działacz społeczny i narodowy na Górnym śląsku. Za kolportowanie książek i broszur religijnych w okresie Kulturkampfu więziony w Mysłowicach. W parafiach, w których pracował (Ziemięcice, Staniszcze), zakładał polskie towarzystwa. Działał także w Towarzystwie dla Szerzenia Elementarzy Polskich im. ks. Engla. Był twórcą Katolickiego Stowarzyszenia Robotników, dostarczał parafianom literaturę w języku polskim, przemawiał na katolickich wiecach i zjazdach, wskazywał, w jaki sposób przeciwstawiać się antypolskim ustawom i zarządzeniom władz, oraz propagował nauczanie języka polskiego w domach. J. Warmiński, Kirchniawy Franciszek ks. [w:] Encyklopedia katolicka, t. 9, red. B. Migut, Lublin 2002, k. 4. 
Od 1874 roku kontynuował naukę w Raciborzu. Tu po ukończeniu czwartej klasy ludowej zdobywał wiedzę w szkole realnej (dwa lata) i w gimnazjum. Był członkiem polskiego kółka samokształceniowego. W szkole wykazywał się dużymi zdolnościami, jednak w 1881 roku, przed maturą, został wydalony z gimnazjum. W 1882 roku wstąpił do reformatów w Krakowie. Trudno powiedzieć, na ile decyzja ta wynikała z odczuwanego przez Statecznego powołania, a na ile z lęku przed reakcją ojca na wieść o usunięciu syna z gimnazjum. Adept życia zakonnego otrzymał imię zakonne Walenty. Nie ukończywszy jednak czasu próby, odszedł z zakonu. Po pewnym czasie wrócił do reformatów. Po odbyciu nowicjatu w Wieliczce w 1885 roku, tym razem jako brat Euzebiusz, złożył pierwsze śluby. Naukę kontynuował w zakładzie teologicznym jezuitów w Krakowie, jednak z powodu lekceważenia zasad obowiązujących w klasztorze został wydalony z zakonu. Wyruszył w podróż do Wenecji. Zgłosiwszy się do konwentu San Francesco della Vigna, za zgodą generała zakonu został przyjęty do tamtejszej prowincji i uzyskał pozwolenie na kontynuację nauki w studium teologii. W 1888 roku złożył wieczyste śluby zakonne, a rok później przyjął święcenia kapłańskie. Wtedy zrodziła się i rozwinęła jego pasja kaznodziejska. Stało się to w dużej mierze dzięki wielkim kaznodziejom, których Stateczny spotkał: o. Augustynowi z Montefeltro OFM i o. Zacchiemu SJ. Poświęcił się studiowaniu kaznodziejstwa, a jednocześnie wykładał filozofię w weneckim studium zakonnym. Następnie pełnił obowiązki profesora filozofii w Wenecji, potem w Mantui (w klasztorze S. Mariae Gratiarum), znów w Wenecji (jako wykładowca dogmatyki i historii Kościoła ${ }^{5}$ ), a następnie w Kolegium św. Antoniego w Rzymie. W okresie weneckim był członkiem zarządu tamtejszej prowincji Zakonu Braci Mniejszych. Ze względu na problemy zdrowotne poprosił o przeniesienie do tzw. bernardyńskiej prowincji w Polsce. Od 1894 roku pełnił tu obowiązki wykładowcy w studium zakonnym we Lwowie. Przez krótki czas pracował w Krakowie, potem został przełożonym klasztoru w Alwerni koło Krakowa. Po pewnym okresie spokojnej i owocnej pracy niespodzie-

5 K. Biliński, A. J. Szteinke, Stateczny Franciszek, [w:] Polski słownik biograficzny, t. 42, red. A. Romanowski, Warszawa-Kraków 2003-2004, s. 567. 
wanie opuścił klasztor i udał się do Rzymu' . Stąd władze zakonne skierowały go do Quaracchi koło Florencji, by podjął powierzone mu obowiązki w tamtejszym kolegium św. Bonawentury. Z Quaracchi wrócił do Rzymu. Z powodów zdrowotnych został skierowany na odpoczynek na Węgry, do klasztoru Maria Radna. Kolejnym miejscem jego pobytu był klasztor w Osiecznej. Potem znów sporo podróżował, odwiedził Niemcy, Francję i Brazylię. Po powrocie do Polski był wikarym parafii we Wronkach, kapelanem zakładu poprawczego sióstr pasterek w Winiarach, pełnił posługę duszpasterską w Goruszkach, Potulicach (jako kapelan hrabiny Anieli Potulickiej) i we Włocławku. Ostatecznie władze zakonne poleciły mu osiąść w klasztorze w Kole.

Pomimo niespokojnego trybu życia, wielu podróży i częstych zmian miejsca zamieszkania sporo pisał7 . Większą część swoich dzieł opublikował, niektóre zaś pozostawił w rękopisie ${ }^{8}$. W literaturze uważany jest za przedstawiciela Młodej Polski w prozie górnośląskiej. W jego prozie dostrzeżono wpływy Żeromskiego i Kasprowicza9. Polski historyk literatury Stanisław Helsztyński umieścił go w swojej galerii meteorów Młodej Polski ${ }^{10}$. Stateczny posługiwał się pseudonimami: Korczewski, Ksiądz, Ksiądz z..., Sta..., Staropolanin, Vitoslavich, krypt. E. S., F. S ${ }^{11}$. Jego dorobek literacki w głównej mierze stanowią nowele i artykuły podejmujące

6 Swojej decyzji o. Stateczny nie omówił z zarządem prowincji, a jedynie - przez osoby trzecie - poinformował o rezygnacji. Zmienność o. Statecznego i nieumiejętność pełnienia podjętych obowiązków przez dłuższy czas wynikały z rozwijającej się w nim choroby psychicznej. A. J. Szteinke, Euzebiusz Franciszek Stateczny OFM (1864-1921) w świetle nowych źródeł, dz. cyt., s. 300; K. Biliński, A. J. Szteinke, Stateczny Franciszek, [w:] Polski słownik..., dz. cyt., s. 567.

7 Pełen wykaz prac o. Statecznego podaje Krzysztof Biliński w swoim opracowaniu: Modernista whabicie..., dz. cyt., s. 141-148.

8 Samoobrona, Samopotępienie, Człowiek $w$ raju, na ziemi i w niebie. Stateczny Euzebiusz Franciszek, [w:] Słownik polskich teologów katolickich, red. ks. H. E. Wyczawski, t. IV, Warszawa 1983, s. 198.

9 A. Bednarek, Kaznodzieja młodopolski, „Przegląd Homiletyczno-Pastoralny” 3 (1999), s. 128 .

10 S. Helsztyński, Inferno w klasztorze, [w:] S. Helsztyński, Meteory Młodej Polski, Kraków 1969, s. 63-86.

$11 \quad$ K. Biliński, A. J. Szteinke, Polski stownik..., dz. cyt. s. 567. 
problematykę społeczną i narodowościową ${ }^{12}$, artykuły i książki religijne ${ }^{13}$, homilie i kazania ${ }^{14}$. Podczas pobytu w Quaracchi opracował dwie rozprawy źródłowe poświęcone św. Bonawenturze: De scriptis Seraphici Doctoris i De vita Seraphici Doctoris. Od 1902 roku publikował na łamach dziennika chrześcijańsko-narodowego „Górnoślązak” jako jego współzałożyciel i członek komitetu redakcyjnego. Ukazały się tam jego opowiadania śląskie, podejmujące tematy polskiej kultury regionalnej zagrożonej germanizacją. Rozpoczął też pisanie trzyczęściowej autobiografii (Samoobrona, Samopotepienie i Wynik). W dziełach tych podjął tematy społeczne i religijne, a także utrwalił swoje stany „okrutnego rozłamania”, jak nazywał czyniącą postępy chorobę psychiczną. Zmarł 6 marca 1921 roku w klasz-

12 Np. Walka kulturna „Górnoślązak” (1902), s. 222-230 (przeróbka Kopciuszka śląskiego); Na łące śląskiej, „Górnoślązak” (1902), s. 228-230; Spór, „Górnoślązak” (1902), s. 233-235, 240, 242-243, 245; Opowiadanie dziadka, „Górnoślązak” (1902), s. 248-249, 251-254; Hasła socjalistyczne a podstawowe prawdy chrześcijańskie, „Miesięcznik Kościelny (Unitas)” (1912) 7, s. 356-371, 442-451 i inne.

13 Np. Św. Polikarp, „Gazeta Kościelna” (1899) 37, s. 300-301; 38, s. 308-309; Św. Symeon, „Gazeta Kościelna” (1899) 41, s. 335-336; Św. Szczepan, „Gazeta Kościelna” (1899) 51, s. 413-414; Św. Piotr i Paweł, „Gazeta Kościelna” (1900) 1, s. 4-6; 3, s. 23-24; 28; Wizerunek ku czci N. Marii Panny, Bytom 1900; Anioł Stróż. Książeczka modlitewna, Bytom 1901; Ołtarzyk. Książeczka modlitewna, Bytom 1901; Wianek. Ksiązeczka modlitewna, Bytom 1901; Wyborek. Ksiażeczka modlitewna, Bytom 1901; Rozbiór krytyczny źródeł do żywota św. Franciszka z Asyżu i literatury franciszkańskiej, Poznań 1913. Druk fragmentów: „Przegląd Kościelny” (1907), s. 81-96, 175-187; „Miesięcznik Kościelny (Unitas)” (1910) 4, s. 166-177, 265-276, 379-386; 8, s. 388-390; (1912) 9, s. 469-471; (1913) 10, s. 72-74; Żywot św. Antoniego z Padwy, Bytom 1909; Żywot św. Franciszka z Asyżu, wyd. I - Poznań 1912, wyd. II - Poznań 1926. Druk fragmentów: „Gazeta Kościelna” (1900), s. 226, 255-257; (1904), s. 61-62, 78-80, 109-110, 160-162; „Przegląd Kościelny” (1904) 6, s. 140-153; (1906) 10, s. 133-144; (1907) 11, s. 341-362; Żywot i pisma Doktora Serafickiego św. Bonawentury, Poznań 1915; Kobieta tercjarka św. Franciszka z Asyżu w odrodzeniu społeczeństwa, Lwów 1916 i inne.

14 Np.Jezus Chrystus. Kazania obejmujące główne zasady wiary chrześcijańskiej, Lwów 1900; Na dzień zaduszny (Kazanie), „Nowa Biblioteka Kaznodziejska” 1907, s. 430-431; Na niedziele 19 po Świątkach (Kazanie). O szczęśliwości i o zbawieniu, "Nowa Biblioteka Kaznodziejska” (1913) t. 14, s. 294-306; Przemowa na poświęcenie sztandaru robotniczego, „Nowa Biblioteka Kaznodziejska” (1913) t. 14, s. 331-335; Przemowa na poświęcenie dzwonów (Kazanie), „Nowa Biblioteka Kaznodziejska" (1913) t. 14, s. 397-409; Na uroczystość św. Jadwigi patronki ślaska i Polski, „Nowa Biblioteka Kaznodziejska” (1913) t. 14, s. 409-419; Na uroczystość św. Franciszka z Asyżu (Kazanie). Św. Franciszek i Trzeci Zakon, „Nowa Biblioteka Kaznodziejska” (1913) t. 14, s. 420-430 i inne. 
torze w Leżajsku. Zatrzymał się tu w drodze na Śląsk, gdzie zamierzał wziąć udział w plebiscycie ${ }^{15}$.

\section{Ogólna charakterystyka Listów o wymowie}

Listy o wymowie powstały na przełomie XIX i XX wieku jako owoc zainteresowań homiletycznych autora. Pierwszy z nich ukazał się w roku 1900 na łamach „Gazety Kościelnej”. Trzynaście lat później tekst, rozszerzony o cztery kolejne listy, ukazał się w częściach na łamach „Nowej Biblioteki Kaznodziejskiej”. W 1920 roku całość została wydana jako książka ${ }^{16}$. Swój wykład na temat wymowy o. Stateczny streszcza w formie pięciu listów skierowanych do fikcyjnego zapewne odbiorcy, nazwanego w tekście „młodym przyjacielem”. Ów ambitny „młody przyjaciel”, chcąc pożytecznie spędzić czas wakacji, pisze do autora:

Czas wakacyjny postanowiłem urozmaicić doskonaleniem się w wymowie, zwłaszcza hieratycznej. Nie chcę drogiego czasu zużywać na bezmyślnym pędzeniu dni, jak tylu innych moich kolegów, lecz wytchnienie należne po pracy szkolnej połączyć z kształceniem się w tym, co mi w zawodzie moim przyszłym rzeczą będzie najpotrzebniejszą.

Kto jest prawdziwym adresatem Listów? We wprowadzeniu autor pisze, że dzieło to ma stanowić zachętę do rozmiłowania się w krasomówstwie i do gorliwego uprawiania tego kunsztu dla ludzi młodych, zwłaszcza ,akademików”, zarówno duchownych, jak i świeckich. Dodaje jednak, że pożytek z lektury tychże listów odniosą wszyscy „wystawieni na trud i powab słowa i którzy w życiu codziennem wystąpić muszą przy jakiejkolwiek sposobności ze słowem publicznie"17. Choć sam autor oczekuje bar-

15 Stateczny Euzebiusz Franciszek, [w:] Stownik polskich teologów..., dz. cyt., s. 197-202; Słownik polskich pisarzy..., dz. cyt., s. 457-463.

16 Listy o wymowie, ,Gazeta Kościelna” (1900) 29, s. 282-285; 30, s. 293-294; 31, s. 304-305; wyd. rozszerzone: „Nowa Biblioteka Kaznodziejska” (1913) t. 14, s. 88-100, 173-180, 258-268, 349-356, 446-452, 516-532; (1913/1914) t. 15, s. 93-104, 195-200, 304-308, 434, 436, 523, 618-620; (1914), s. 96-100, 171-172, 280-284, 390-396, 492-496, 592-601. To samo w wydaniu osobnym: Listy o wymowie, Poznań-Warszawa 1920.

17 E. Stateczny, Listy..., dz. cyt., s. V-VI. 
dzo szerokiego grona odbiorców, lektura tekstu daje wyraźne odczucie, że jego odbiorcą jest przede wszystkim kleryk przygotowujący się do pracy kaznodziejskiej lub młody ksiądz. Hipotezę tę potwierdza także fakt, że Listy pierwotnie były opublikowane w „Nowej Bibliotece Kaznodziejskiej”.

Prośba skierowana do autora precyzuje oczekiwania dotyczące formy mającego powstać zbioru wskazań: „Proszę cię tylko, nie pisz ani drobiazgowo i gołosłownie jak Francuz, ani uczenie i sucho jak Niemiec. Bądź sobą, a wtedy będę miał po Tobie prawdziwą pamiątkę i zachętę"18. Stateczny zaznacza, iż jego zamiarem nie jest stworzenie podręcznika krasomówstwa czy homiletyki ani dokonanie pełnego opracowania tematu ${ }^{19}$.

Z całą pewnością dzieło to stanowi ciekawe i oryginalne kompendium wiedzy dla pragnących doskonalić swe umiejętności oratorskie. Jego przejrzysta konstrukcja i równomierne rozłożenie materiału sprawiają, że czytający Listy o wymowie z łatwością mogą sobie przyswoić zawarte w nich wskazówki.

Na uwagę zasługuje poetycki, bardzo obrazowy język autora. Używa on sformułowań przemyślanych, dopracowanych, choć niekiedy mogących razić współczesnego odbiorcę barokowym stylem: „Gdy z pełnych okrągłych piersi wypuści mówca strumień powietrza w nagłośnię, a ta pod palcami wiązadeł zagra barwnymi tony, zdaje się jakby dźwięk złota i srebra się odbijał lub perły przezroczyste wytaczały się z gardła"20. Ciekawy wątek stanowią używane przez niego analogie muzyczne. Mówiąc o głosie wysokim, porównuje go do fortepianu wydającego dźwięki na wielkiej przestrzeni i mandoliny mającej wybrzmieć w sali o kiepskiej akustyce. Głos gruby porównuje do wiolonczeli, której dźwięk wypełnia „przestrzeń i dochodzi do wszystkich słuchaczy, ale ma w sobie coś z grzmotu huczącego"21.

Rodzi się pytanie, na ile Listy o wymowie stanowią samodzielną pracę autora, a na ile kompilację ówczesnych publikacji ${ }^{22}$. Sam Stateczny przy-

\footnotetext{
$18 \quad$ E. Stateczny, Listy..., dz. cyt., s. 1.

19 E. Stateczny, Listy..., dz. cyt., s. 48.

$20 \quad$ E. Stateczny, Listy..., dz. cyt., s. 10.

${ }_{21}^{21}$ E. Stateczny, Listy..., dz. cyt., s. 13.

${ }^{22}$ K. Biliński, podkreślając szerokie spektrum tematyczne publikacji Statecznego, pisze: „Wielość problemów filozoficznych, teologicznych, społecznych, politycznych, a nawet patriotycznych wzbudza w literaturoznawcach niemałe wątpliwości, w jakim stopniu
} 
znaje, że pisząc trzeci i czwarty list, posiłkował się Stylistyką autorstwa Piotra Chmielowskiego ${ }^{23}$.

\section{Analiza treści}

Już na wstępie o. Stateczny zaznacza, że swój wykład zamierza podać „w przejrzystym całokształcie”. Cechy, które powinien posiadać doskonały mówca i jego dzieło, autor porządkuje według następującego klucza: 1. Zalety zewnętrzne podmiotowe. 2 . Zalety wewnętrzne podmiotowe. 3. Zalety zewnętrzne przedmiotowe. 4. Zalety uzupełniające. 5. Zalety nadprzyrodzone. Określenia te brzmią dziś nieco archaicznie, dlatego na użytek niniejszego opracowania nazwiemy je następująco: 1. Przymioty retoryczne mówcy. 2. Przymioty osobiste. 3. Cechy dzieła oratorskiego. 4. Doświadczenie i erudycja. 5. Czynniki nadprzyrodzone. Ponieważ o. Stateczny w kolejnych punktach swojej rozprawy nie dokonał wyraźnego podziału na cechy mówcy i cechy dzieła, pogrupujmy je nieco inaczej, w myśl zasady agere sequitur esse: Najpierw prześledźmy spostrzeżenia i wskazania autora dotyczące mówcy (3.1.), a w dalszej kolejności cechy dzieła oratorskiego (3.2.).

\subsection{Spostrzeżenia i wskazania dotyczące mówcy}

Większą część swojego wykładu o. Stateczny poświęca osobie mówcy. Swoje spostrzeżenia i wskazania porządkuje według następującego klucza: przymioty osobiste, doświadczenie i erudycja, przymioty retoryczne, czynniki nadprzyrodzone. Podział ten umożliwia możliwie całościowe spojrzenie na osobę oratora.

Stateczny był twórcą oryginalnym, a w jakim - rezonerem cudzych opinii”. Na uwagę tę daje następującą odpowiedź: „Gdy chodzi o dzieła drukowane, Stateczny rzadko silił się na oryginalność i samodzielność. Z kolei w intymnych rękopisach - pamiętnikach starał się zawrzeć maksimum życiowej prawdy połączonej z literacką fikcją". K. Biliński, Modernista w habicie..., dz. cyt., s. 7-8.

${ }^{23}$ E. Stateczny, Listy..., dz. cyt., s. VI; P. Chmielowski, Stylistyka polska wraz z nauka kompozycyi pisarskiej, Warszawa 1903. 


\subsubsection{Przymioty osobiste}

Tę grupę cech określa o. Stateczny mianem zalet pod mi ot ow y ch wewnętrznych. Tytułem wstępu pisze, iż mowa musi być osadzona w jaźni człowieka. Źródłem wymowy są te władze człowieka, które stanowią jego istotę: rozum, wola (afekt) i wyobraźnia. Uważa, że winny być one zrównoważone, tymczasem u mówców często przeważa jedna $\mathrm{z}$ nich.

Nie chcąc dawać pierwszeństwa żadnej ze wspomnianych trzech władz, stwierdza, że mowa bez ro zu mu byłaby gadulstwem. Rozum jest konieczny przy wyborze tematu, jego zrozumieniu, rozwinięciu, przeprowadzeniu i obronie. Uznając złożoność rozumu ludzkiego, wyróżnia trzy jego kategorie: logiczny, analityczny i syntetyczny. Logika według niego jest w mowie warunkiem sine qua non. Tylko dzięki niej mówca zdoła przekonać słuchacza do swoich racji. „Chcesz nawrócić lud? - pisze - przemów doń logicznie, przemowę poprzyj własnym czynem i przykładem, a lud poleci za tobą jak w obłędzie"24. Mówca analityczny nie zaczyna od wizji kontemplacyjnych i definicji, ale od szeregowania faktów i pojedynczych prawd i układania ich w całość. Rozumowanie syntetyczne jest według Statecznego cechą rozumów genialnych, gdyż należy do trudniejszych, ale gdy zostanie właściwe przeprowadzone, osiąga dobry skutek.

Drugą władzą wewnętrzną człowieka przywołaną w kontekście przymiotów osobistych jest w o la nazywana przez autora „afektem” i rozumiana jako perswazja, zapał, który udziela się słuchaczowi. Uważa, iż wola mówcy, wola mowy i wola słuchaczy muszą się pokrywać, ponieważ niezgodność między nimi prowadziłaby do klęski. Wola charakteryzuje się różną intensywnością. Autor rozróżnia tu trzy rodzaje mówców: tych, którzy nie chcą zapalić audytorium, a jedynie pouczyć; tych, którzy pragną zapalić słuchaczy do czynu, ale czynią to stopniowo; tych wreszcie, którzy kilkoma zaledwie słowami natychmiast porywają słuchaczy. Stateczny wymienia trzy rodzaje woli: słabą, wahającą się i mocną. Jako przyczyny słabości woli mówiącego podaje: nieumiejętne opracowanie tematu lub nieudolny przekaz, brak osobistego przekonania do przekazywanych treści, ubogą treść. Mówcami o woli wahającej się nazywa tych, których słowa od-

$24 \quad$ E. Stateczny, Listy..., dz. cyt., s. 35. 
noszą różne skutki: raz porywają, raz koją i pocieszają, czasem odpychają i gorszą, innym zaś razem usypiają i nudzą. Autor pisze dosadnie, że taka mowa jest nieznośna i „działa na nerwy jak piła”25. Niebezpieczeństwo takiego mówienia dostrzega przede wszystkim u tych, którzy przygotowują wystąpienia jedynie w myśli, co utrudnia im właściwe rozłożenie akcentów i powoduje wpadanie w skrajności: od przesadnego namaszczenia do jego braku ${ }^{26}$. Trzeci rodzaj woli to wola mocna. Autor twierdzi, że wola obok rozumu jest głównym czynnikiem wymowy.

Trzecim przymiotem wewnętrznym mówcy jest w y o b raźni ia. Choć niezbędna w wymowie, zajmuje niższe miejsce niż omówione wcześniej rozum i wola. Mówcy charakteryzują się rozmaitymi stopniami wyobraźni. Stateczny wskazuje trzy jej rodzaje: przyswojoną, błyskotliwą i poetyczną. Odnośnie do pierwszej z nich autor wyraża przekonanie, że owoce wyobraźni mogą pochodzić „,z otchłani i skarbnicy wewnętrznej” ${ }^{27}$ albo z przyswojenia sobie cudzych natchnień, myśli i obrazów. Inspiracją dla mówcy mogą stać się nawet jego słuchacze, obrazy i zwroty, którymi się posługują. Wyobraźnię błyskotliwą plasuje nieco wyżej niż przyswojoną. Cechuje ją brak umiejętności tworzenia nowych obrazów połączony ze zdolnością sprytnego używania obrazów cudzych, umiejętne żonglowanie nimi, „cudowna moc małpowania, kradzenia i maskowania"28. Na najwyższym miejscu stawia autor wyobraźnię poetyczną ${ }^{29}$. Mówca taki, choćby nie był mistrzem w swoim warsztacie, zawsze będzie słuchany z uwagą. Przywołując łacińską sentencję mówiącą, że poetą człowiek się rodzi, a oratorem się sta$\mathrm{je}^{30}$, zauważa, że prawdziwy poeta - choć nie bez trudności - może stać się mówcą, ale mówca nie stanie się poetą. Dobremu mówcy wyobraźnia poetyczna dodaje coś, co olśniewa i porywa słuchaczy.

25 E. Stateczny, Listy..., dz. cyt., s. 44.

26 „Konie są wprawdzie zaprzężone, ale woźnica (mówca) nie umie nimi jechać: to galopem, to stępem, to zamęczonym zamieraniem, to przeraźliwą jednostajnością". E. Stateczny, Listy..., dz. cyt., s. 43.

$27 \quad$ E. Stateczny, Listy..., dz. cyt., s. 49.

28 E. Stateczny, Listy..., dz. cyt., s. 51.

29 „Poezji nikt oprzeć się nie zdoła, choćby i w siermiędze, i w koszuli zgrzebnej była. A cóż dopiero gdy poeta przemówi jako mówca wykończony i natchniony". E. Stateczny, Listy..., dz. cyt., s. 53.

30 W oryginale: „Poëta nascitur, orator fit”. E. Stateczny, Listy..., dz. cyt., s. 53. 


\subsubsection{Doświadczenie i erudycja}

W grupie przymiotów określonych jako zalety uzupełniające autor wymienia: doświadczenie, wykształcenie i sztukę. Uzbrojony w nie mówca może stanąć przed jakimkolwiek audytorium i mówić na jakikolwiek temat, będąc pewnym, że jego słowo odniesie pożytek i będzie dziełem sztuki. Na pierwszym miejscu stawia d oś w i a d c ze n i e. By prowadzić innych, samemu trzeba znać drogę, i to znać ją lepiej niż słuchacze. Mówienie niepoparte doświadczeniem przynosi niewielkie owoce. By zdobyć doświadczenie, potrzebna jest umiejętność obserwacji, korzystania ze spostrzeżeń własnych i innych ludzi. Autor ukazuje potrzebę posiadania doświadczenia życia wewnętrznego, życia społecznego i potrzebę znajomości doświadczenia innych ludzi.

Na drugim miejscu stawia autor w y k s z t ał c e n i e. Przywołując słowa Horacego: „Początkiem i źródłem dobrego pisania jest mądrość” ${ }^{1}$, odnosi je także do mówienia. Mówca powinien być wszechstronnie wykształcony, a przynajmniej dobrze poznać omawiany problem. Jako trzy źródła wykształcenia autor podaje: oczytanie, odczuwanie i podróżowanie.

$\mathrm{Na}$ trzecim miejscu wymienia sztukę. Jak pisze, bez sztuki nie ma krasomówstwa. Doskonały mówca obok tego, że ma być po części psychologiem, filozofem, człowiekiem uczonym i doświadczonym, ma też być artystą. Artystą i mistrzem jest mówca umiejący połączyć naturalność i sztukę. Stoją więc przed nim trzy zadania: poznać zasady retoryki, stosować prawa prozy i poezji, posługiwać się plastyką stylu i mowy. Mówca powinien znać zasady gramatyki, logiki, psychologii wiążące się ze stylistyką i retoryką. Autor podaje pięć cech poprawnej mowy: 1. poprawność gramatyczna; 2. czystość językowa; 3. powiedzenie tego, co chciało się powiedzieć; 4. jasność mówienia, by słuchacz umiał zrozumieć myśli i zamiar mówcy; 5. zwięzłość - używanie takiej ilości wyrazów, jaka jest niezbędna do należytego wyrażenia myśli. Autor oczekuje też od mówcy znajomości figur retorycznych. Stosowanie prawideł stylistyki we własnym utworze uważa za najwyższy stopień umiejętności retorycznej: 1. Daną myśl jasno sobie uprzytomnić, a potem dopiero

31 W oryginale: „Scribendi recte sapere est et principium et fons - Dicendi recte sapere est et principium et fons". E. Stateczny, Listy..., dz. cyt., s. 96. 
szukać dla niej odpowiedniej szaty - nie odwrotnie. 2. Przemieniać myśli na uczucia i obrazy fantazji. 3. Dbać o jakość wyrazu myśli i uczuć. Po to istnieje różnorodność postaci retorycznych, aby nimi wyrazić różnorodność i jakość myśli, uczuć i wyobraźni. 4. Dbać o różnorodność postaci krasomówczych samą w sobie. 5. Pamiętać, że piękna mowa potrzebuje swego cienia i światła, jak piękny obraz. Mowa nie może zawierać w sobie nadmiaru obrazów i figur. Są w niej treści ważniejsze i mniej istotne. Dobry mówca musi też być dobrym stylistą. Aby wykazać się plastyką stylu, trzeba dysponować plastyką wyobraźni. Jako szczególne okazje do wykorzystania tej umiejętności podaje autor opisy męki Chrystusa, opis stworzenia świata i żywoty świętych męczenników.

\subsubsection{Przymioty retoryczne mówcy}

Zewnętrzne narzędzia, którymi posługuje się mówca, jego przymioty retoryczne określa autor mianem zalet zewnętrznych podmi ot ow y ch. Do grupy tej zalicza słow o, głos i ruch. Wyraża przekonanie, że słowo jest jednakowe u wszystkich mówców, a to, co świadczy o ich odrębności, to jakość głosu i różnorodność ruchu. Jak zauważa o. Stateczny, nie jest możliwe wypracowanie harmonii między słowem, głosem i ruchem w stopniu doskonałym. Jest ona darem Boga i dziełem natury, a systematyczne ćwiczenia są w stanie jedynie rozwinąć wrodzone umiejętności. Mówca, który nie został nimi obdarzony, brak ten na próżno będzie nadrabiał kunsztem ${ }^{32}$.

Mówiąc o słowie, autor ma na myśli m.in. kwestie artykulacyjne. Wylicza trzy rodzaje artykulacji: wargową, zębową i gardłową ${ }^{33}$. Przez artykulację wargową rozumie, jak sam to określa, mówienie „cienkimi wargami”, na „zesznurowanych wargach”. Przyznaje, iż czasem ten typ mówienia jest uzasadniony, ale używanie go nagminne mogłoby świadczyć o tkliwości i nadmiernej delikatności mówcy. Zasadność artykulacji zębowej dostrzega wtedy, gdy słowo nacechowane jest ,zmysłowością gwałtowną" lub wrodzo-

\footnotetext{
32 E. Stateczny, Listy..., dz. cyt., s. 5.

33 „Atoli i głos, i ruch jest różnorodny u każdego mówcy, zatem i słowo żywe ma swoją odrębną barwę. Według tej barwy sądząc, można słowo żywe podzielić na wargowe, zębowe i gardłowe według miejsca głosu i wprawy poszczególnych organów, na których słowo osiada". E. Stateczny, Listy..., dz. cyt., s. 6.
} 
ną ironią mówcy. Podobnie jak w przypadku artykulacji wargowej, umiejętnie użyta może przynieść korzyść, nieumiejętnie - szkodę. Trzeci typ to artykulacja gardłowa. Autor definiuje ją jako sztuczne „odcięcie”, którym mówca „pewne ustępy ożywić i upiększyć pragnie. [...] Ustęp wymówiony nabiera jakiejś powagi i zdaje się, jakby z głębokości duszy pochodził”. Zabiegi te - czasem wskazane - używane zbyt często, odnoszą skutek odwrotny do zamierzonego - męczą i mówcę, i słuchaczy.

Kolejnym zagadnieniem, które podejmuje autor, jest g ło s. Postrzega go jako wielki atut mistrzów słowa. Posuwa się nawet do sformułowania: „Człowieka, którego natura wyposażyła pięknym głosem, chciała też mieć mówcą" ${ }^{34}$. Pisze, że jak piękno głosu czyni człowieka zdatnym do bycia mówcą, tak umiejętna modulacja czyni z niego mistrza ${ }^{35}$. Wyróżnia trzy typy głosu: wysoki, niski i średni. Większości mówców przypisuje głos wysoki. Nie zawsze jest on przyjemny dla ucha, zwłaszcza gdy przybiera barwę „krzykliwą, piskliwą, skrzypiącą, drewnianą i z tak zwanym dyszkantem"36. Jednym z mankamentów wysokiego głosu jest jego wąska skala. Autor zauważa, że rzadko trafia się głos wysoki, który byłby jednocześnie „dźwięczny, okrągły i miękki” ${ }^{37}$. Choć taka barwa głosu nie dyskwalifikuje mówcy, musi on użyć innych atutów, by uwaga słuchaczy nie skupiła się jedynie na niej. Jako drugą skrajność podaje głos zbyt niski. Dostrzega co prawda, że jego brzmienie może być miłe dla ucha, ale w swym brzmieniu jest on głuchy i niewyraźny. Stateczny uważa, że choć głos taki ma swoje zastosowanie, to jednak jego posiadacz najczęściej dysponuje wąską skalą, która utrudnia mu wyrażenie wszystkich uczuć. Najbardziej pożądany jest głos średni. Wymaga on odpowiedniej modulacji, by mógł wyrażać to, co kryje się w sercu mówiącego ${ }^{38}$.

Trzecim problemem podjętym przez autora w punkcie dotyczącym zalet zewnętrznych podmiotowych jest $\mathrm{r}$ u ch. Ukazuje go jako dopełnienie słowa i głosu. Pierwszą częścią ciała mówcy, na której można dostrzec

\footnotetext{
E. Stateczny, Listy..., dz. cyt., s. 10.

E. Stateczny, Listy..., dz. cyt., s. 10.

E. Stateczny, Listy..., dz. cyt., s. 11.

E. Stateczny, Listy..., dz. cyt., s. 12.

E. Stateczny, Listy..., dz. cyt., s. 15-16.
} 
ruch, jest twarz ${ }^{39}$. Autor zauważa, że mimika winna oddawać to, co niesie ze sobą słowo. Przestrzega przed sztucznością, która może przynieść efekt maski lub dziecinnego przedrzeźniania. Kolejnym zagadnieniem, które porusza autor, jest gestykulacja. Mówca całym sobą, w wyważony sposób, ma wyrażać uczucia, które są obecne w jego duszy. Stateczny wyróżnia trzy typy ruchu: rzadki, ciągły i umiarkowany. Jeżeli chodzi o mimikę twarzy, którą autor nazywa zwierciadłem duszy, ruch powinien być częsty. Twarz winna się płynnie zmieniać wraz z tokiem mowy. Jeżeli chodzi o ręce, autor uważa, że ich ruch w czasie mówienia nie powinien być ani zbyt częsty, ani zbyt rzadki - ma być umiarkowany. Gestykulacja winna być barwna, wyraźna, szlachetna, odpowiadająca myślom, uczuciom i obrazom pojawiającym się w toku mowy.

\subsubsection{Czynniki nadprzyrodzone}

Czynnikom nadprzyrodzonym poświęca autor ostatni, piąty list. Wymienia wśród nich: chwałę, łaskę i miłość. Pisze, że najbardziej szczytnym i rozumnym celem człowieka jest działanie na chw ałę Bożą. Jako jedno z najważniejszych dążeń oratora postrzega mówienie na chwałę Bożą, co rozumie jako oddawanie należnego szacunku Bogu, a w Bogu wszystkim innym stworzeniom, w tym samemu sobie. Mówcę porównuje do poety, który wszystko to, co widzi na świecie, winien wiązać w całość i składać na chwałę Bogu ${ }^{40}$. Jako głosiciela chwały Boga postrzega nie tylko mówcę kościelnego, ale i świeckiego, np. adwokat czy prokurator głoszą chwałę Bożą objawiającą się w prawie i sprawiedliwości społecznej. W mowie mogą pojawić się także elementy chwały narodowej, a nawet osobistej.

${ }^{39}$ Także współcześni teoretycy kaznodziejstwa poświęcają temu zagadnieniu sporo miejsca: „Twarz, najbliższa ośrodkom psychicznym, uchodzi za zwierciadło duszy. W niej odbijają się wewnętrzne przeżycia mówcy wymowniej niż w ruchach rąk i postawie ciała. Twarz jest bogato unerwiona, działa w niej 14 par mięśni, z których każdy służy wyrażeniu odpowiednich stanów wewnętrznych". J. Twardy, Zachowanie kaznodziei na ambonie, [w:] Mowa żywa. Wybrane aspekty komunikacji kaznodziejskiej. Sympozjum Sekcji Homiletów Polskich. KielceSkorzeszyce 27-28 X 2003, red. J. Twardy, W. Broński, J. Nowak, s. 177.

40 E. Stateczny, Listy..., dz. cyt., s. 127. 
Jako nadprzyrodzoną pomoc dla mówcy postrzega ła s kę Bożą. Omawia pokrótce trzy sposoby otwarcia się człowieka na ten dar: modlitwę, kontemplację i pracę. Mówiąc o modlitwie, jako przykład przywołuje postaci kaznodziejów: ks. Goliana, ks. Wajdy, który przemawiał w parlamencie niemieckim i ks. Gąsiorowskiego - proboszcza z Niepołomic. Ich żarliwa modlitwa przed zabraniem głosu sprawiała, że łaska Boża towarzyszyła im samym i tym, do których mówili. Jako drugi sposób otwarcia się na łaskę wskazuje kontemplację. Mówca winien być nie tylko obyty w kontemplacji; ma być jej mistrzem. Jako pomoc w zrozumieniu tego zagadnienia Stateczny proponuje dwa dzieła św. Bonawentury: Itinerarium mentis in Deum i De reductione artium ad theologium ${ }^{41}$. Zgłębienie ich prowadzi - jego zdaniem - do osiągnięcia mistrzostwa w krasomówstwie. Trzecim „oknem”, przez które dociera do człowieka łaska Boża, jest praca. Modlitwa i kontemplacja dzięki pracy mają być zamienione w czyn. Bez pracy nie ma widocznych skutków kontemplacji i modlitwy.

Jako trzeci czynnik metafizyczny mający towarzyszyć oratorowi Stateczny podaje miłość. Miłość mówcy do słuchaczy ma emanować nie tylko poprzez słowo. Ma być widoczna także podczas spotkań ze słuchaczami. Miłość do słuchaczy i wynikająca z niej odpowiedzialność będzie go mobilizować do życia zgodnego z tym, czego naucza. Autor, mówiąc o miłości mówcy do słuchacza, wspomina także o miłości słuchacza do mówcy i ich wspólnej miłości w Chrystusie. Miłość mówiącego budzi miłość słuchaczy: „Gdy lud ujrzy swego prawdziwego przyjaciela, pełnego miłości i poświęcenia, jego serca idą doń na oślep, gotów zań głowę położyć, bronić, iść za jego skinieniem na życie i śmierć" ${ }^{42}$. Zauważa, że zjawisko to dotyczy nie tylko mówców kościelnych, choć jako przykład przywołuje tu św. Antoniego z Padwy. Między mówcą a słuchaczami ro-

${ }^{41}$ W latach 1901-1902 autor pracował w Kolegium Wydawniczym św. Bonawentury przy franciszkańskim klasztorze w Quaracchi, gdzie uczestniczył w pracach nad wydaniem dzieł Doktora Serafickiego. Stąd jego dobra znajomość tego zagadnienia. K. Biliński i A. J. Szteinke, Polski słownik..., dz. cyt., s. 567.

42 „A mówca? Dlań słuchacze zmysły i miarę rozumu tracą. Kwieciem go obsypią, oklaskami i okrzykami zagłuszą, konie od jego powozu odprzęgną i sami się wprzęgną, szaty mu porozdzierają, a kawałki jego jako relikwie do domów swych poniosą". E. Stateczny, Listy..., dz. cyt., s. 163. 
dzi się szczególna więź, którą nazywa wspólną miłością w Chrystusie. Ma tu na myśli sytuację idealną, kiedy „pomiędzy mówcą a jego audytorium tworzy się prąd ciągły miłości i gotowości poświęcenia, dlatego iż prowadzą ze sobą swojego rodzaju cudowną wymianę uczuć, myśli i zamiarów i porozumiewają się w tajemniczy sposób" ${ }^{43}$. Zauważa, iż dopóki osobno mówi się o miłości mówcy i miłości słuchaczy, pożądane jest umiarkowanie. Natomiast w przypadku ich wspólnej miłości w Chrystusie ograniczenie nie jest potrzebne.

\subsection{Cechy dzieła oratorskiego}

Kolejnym zagadnieniem, które podejmuje o. Stateczny, są cechy dzieła oratorskiego, które nazywa zaletami zewnętrznymi przedmiotowymi. Zalicza do nich treść, poezję i tragiczność. Te trzy właściwości powinna posiadać mowa właściwie zbudowana. Pierwszym elementem potrzebnym, by mowa zaistniała, jest treść: Trzeba mieć coś do powiedzenia. Drugi element - poezja, to coś nieuchwytnego, co nadaje dziełu szlachetności. Krasomówstwo jest sztuką, a każda sztuka - jak twierdzi autor - jest córką poezji. Trzeci element to tragiczność. Bez pierwiastka tragicznego nie obejdzie się żadne dzieło sztuki, zatem i krasomówstwo musi mieć go w sobie - pisze Stateczny.

Mówca najpierw powinien być człowiekiem, który ma coś do powiedzenia. Mowa będzie tym doskonalsza, im bogatsza w tre ść (choć i tu trzeba zachować umiar ${ }^{44}$ ). Treść ma być dopasowana do możliwości percepcyjnych słuchaczy. Stateczny pisze o treści doczesnej, religijnej i wzniosłej. Twierdzi, iż treść doczesna może występować także na ambonie: „Ambona wtedy święci swoje najtrwalsze triumfy i zbiera najpiękniejsze owoce, gdy się przemienia w szkołę i naukę, i oświatę publiczną”, gdyż „prawdy religijne wspierają się także na treści doczesnej”45.

$43 \quad$ E. Stateczny, Listy..., dz. cyt., s. 166-167.

${ }^{44}$ Autor z właściwą sobie umiejętnością obrazowania słowa dzieło mówcy, który chce zawrzeć w nim zbyt wiele treści nazywa „grochem z kapustą”, , pstrym gałgankiem” i „dziecinną gadaniną". E. Stateczny, Listy..., dz. cyt., s. 60.

45 E. Stateczny, Listy..., dz. cyt., s. 61. 
Wbrew swej nazwie treść doczesna powinna zmierzać także do tego, co wzniosłe, do jakiegoś ideału. Uprzywilejowanym miejscem głoszenia treści religijnej jest ambona. Pierwszorzędnymi jej źródłami są Pismo Święte, Tradycja i nauka Kościoła, drugorzędnymi - rozum objawiający się w naukach ścisłych, filozoficznych, w historii, doświadczeniu i sztuce. Jeżeli chodzi o treść wzniosłą autor uważa, że ogniskuje się w niej treść i doczesna, i religijna.

Drugim elementem pożądanym w dziele oratorskim jest po e z j a ${ }^{46}$. Autor pojmuje ją jako środek udoskonalający mowę. Krasomówstwo mogłoby się bez niej obejść, ale stałoby się jałowe. Mówca powinien czerpać z poezji z umiarem: na tyle, na ile pozwalają zasady retoryki, naturalność i zdolności mówcy. Pod pojęciem „poezja” rozumie nie szatę poetycką, ale coś nieuchwytnego, dzięki czemu nawet proza potrafi sięgnąć w krainę poezji. Czynnik poetyczny w krasomówstwie autor dzieli na poezję sielankową, liryczną i dramatyczną. Poezja sielankowa w obrębie krasomówstwa nacechowana jest prostotą i odniesieniami do codziennego życia. Wymaga to od mówcy znajomości życia słuchaczy, aby z niego czerpać obrazy i porównania. Poezji lirycznej mówca nie powinien nadużywać, ale stosować ją tylko we właściwych okolicznościach. „Nieodpowiednio użyta poezja liryczna, albo w niezgrabnych rękach artysty usiłującego wciąż stroić lirę płaczu i rzewliwości, i słodkawych pieszczot, budzi niesmak i przesyt, a podczas gdy kilka dewotek zajęczy sztucznie, oczy serca rozumnych słuchaczy pozostaną suche, a usta zdradzają znudzenie i zniechęcenie" ${ }^{47}$. Pisze o. Stateczny, że skoro wymowa jest pewnego rodzaju dramatem, nie może się obejść bez czynnika dramatycznego. Jak w dramacie obecny jest ciągły konflikt, tak i w prozie oratorskiej ścierają się sprzeczne sądy, zdania, chęci, aby ostatecz-

${ }^{46} \quad$ K. Müller w swojej książce Homiletyka na trudne czasy pisze, że teologia chrześcijańska i poezja od początku pozostawały w skomplikowanej, pełnej napięcia relacji, mimo iż niektóre fragmenty, a nawet całe księgi Pisma Świętego pisane były poetyckim językiem. Niszą, w której dopuszczano poetycki sposób mówienia, było kazanie. „Rehabilitacja poetyckości dokonała się spontanicznie i intuicyjnie wszędzie tam, gdzie głoszono kazania - i gdzie się je głosi. Ponieważ nie sposób inaczej, tzn. bez poetyzacji”. K. Müller, Homiletyka na trudne czasy, Kraków 2003, s. 147.

${ }_{47} \quad$ E. Stateczny, Listy..., dz. cyt., s. 71. 
ne zwycięstwo odniosła prawda. Przywołując Karola Mecherzyńskiego, autora dzieła zatytułowanego Historia wymowy w Polsce $e^{48}$, pisze, że dramat na scenie, a wymowa na mównicy przedstawiają żywą i pełną poruszenia akcję.

Trzecią cechą dzieła oratorskiego winna być tr a g i c z n o ść. W mowie - czy to doradczej, czy sądowej, czy religijnej- winien pojawić się element tragiczny, który słuchaczy porusza i pobudza do zastanowienia. Tragizm pojawiający się w krasomówstwie może pojawić się jako opis, polemika i obraz. Opis nie należy, według Statecznego, do zadań łatwych. Musi być plastyczny, żywy, czasem nawet tragiczny, okraszony przenośniami, porównaniami i innymi zabiegami stylistycznymi. Polemika zajmuje szczególne miejsce w krasomówstwie. Próbuje ona naświetlić pewne kwestie sporne. Jedne z nich ukazuje jako słuszne, wykazując równocześnie niepoprawność innych. Ta walka między teoriami powinna być szlachetna, spokojna i rzeczowa. Powinna być sporem nie z osobą, ale z błędem i fałszywą teorią. Obraz przemawia do wszystkich władz duszy ${ }^{49}$ i stanowi dla mówców wielką wartość.

\section{Aktualność Listów o wymowie}

Z całą pewnością niektóre stwierdzenia autora zawarte w tekście prowokują do dyskusji, choćby to, które mówi, że słowo jest jednakowe u wszystkich, a dopiero barwa głosu i ruch nadają mu cech charakterystycznych. Trudno zgodzić się z tym twierdzeniem. Tak jak każdy ma własny charakter pisma, tak też dysponuje właściwymi sobie cechami komponowania wypowiedzi, posługuje się słowem na swój sposób. Dobór i kompozycja tworzywa leksykalnego nie są przecież jednakowe dla wszystkich. Niemniej Listy o wymowie zawierają wiele aktualnych spostrzeżeń, choć

\footnotetext{
${ }^{48}$ K. Mecherzyński, Historya wymowy w Polsce, t. 1, Kraków 1856; t. 2, Kraków 1858; t. 3 , Kraków 1860.

49 Stateczny przywołuje tu kazanie jezuickiego kaznodziei ks. Zocchi na temat czyśćca. Posłużył się on serią obrazów, które sprawiły, że audytorium „stało olśnione, przygwożdżone, skamieniałe pod potęgą prawdy, piękna, tragizmu w plastyce obrazowej”. E. Stateczny, Listy..., dz. cyt., s. 79.
} 
powstały ponad sto lat temu. Istnieją bowiem wskazania, które mimo upływu lat nie tracą na aktualności ${ }^{50}$.

Na szczególną uwagę zasługuje umiejętne wykorzystywanie przez autora osiągnięć retoryki ${ }^{51}$. W procesie formowania mówców kościelnych naszych czasów kładzie się na nią szczególny nacisk ${ }^{52}$. Nie tylko pomaga ona zrozumieć wartość słowa, ale także umożliwia zdobycie umiejętności tworzenia własnych tekstów; przypomina o potrzebie kształcenia mówców, pozwala doświadczyć piękna słowa mówionego, dostarcza środków skutecznego przemawiania ${ }^{53}$.

Autor słusznie uświadamia adresatowi listów, że praca nad doskonaleniem własnej wymowy wymaga cierpliwości: „Musi się rozwijać stopniowo, a nie z przeskokami; rozumowo, a nie instynktownie; wytrwale, a nie fruwaniem" 54 . Ponadczasową prawdą jest stwierdzenie, że mówca musi pamiętać, o czym ma mówić, jak, kiedy, wobec kogo i gdzie. Znalezienie odpowiedzi na te pytania wywiera niemały wpływ na kształt i strukturę mowy ${ }^{55}$. Trudno nie zgodzić się także z tym przekonaniem autora: „Jest to jeden

50 Ks. prof.K. Panuś pisze: „Niewątpliwie dzieła dawnych mówców kościelnych nie mogą być współczesnymi podręcznikami homiletyki, zbiorem wzorów do naśladowania, kompendium przykładów [...] niemniej wielu z dawnych kaznodziejów może pomóc w przygotowaniu współczesnej homilii”. Co prawda słowa te odnoszą się do tekstów kazań, jednak można je odnieść także do wskazań homiletycznych, które zawarte są m.in. w dziele o. Statecznego. K. Panuś, Rola historii kaznodziejstwa w procesie kształcenia kaznodziei, [w:] Integralne kształcenie kaznodziei, red. ks. W. Broński, Lublin 2006, s. 261.

51 Homiletyka jest nauką o charakterze kontekstualnym, korzysta z osiągnięć różnego rodzaju nauk, które spełniają wobec niej pomocnicze zadania. Podobną rolę powinna pełnić w niej retoryka rozumiana jako ars bene dicendi. G. Siwek, Miejsce retoryki whomiletyce, [w:] Retoryka dziś. Teoria i praktyka, red. R. Przybylska, W. Przyczyna, Kraków 2001, s. 299. Powiązania retoryki z homiletyką w interesujący sposób ukazują także: H. Sławiński, W. Przyczyna, Homiletyka a retoryka. Przeszłość, teraźniejszość, przyszłość, „Przegląd Homiletyczny” 9 (2005), s. 133-141; H. Sławiński, Retoryka w przepowiadaniu słowa Bożego - historia i aplikacja na przykładzie homilii Jana Pawła II wygłoszonej we Włocławku 7. 06. 1991 r., [w]: Jan Paweł II apostoł prawdy, red. J. Kędzierski, Włocławek 2005, s. 283-292.

52 M. Korolko, Podręcznik retoryki homiletycznej, oprac. G. Jaśkiewicz, Kraków 2010, s. 10. A. Borowski pisze, że retoryka jest warunkiem powodzenia kaznodziei, a także wydaje się coraz bardziej istotnym składnikiem edukacji społecznej. Zob. A. Borowski, Kaznodzieja jako retor, [w:] Stuga słowa, red. W Przyczyna, Kraków 1997, s. 183.

53 G. Siwek, Retoryka w procesie kształcenia kaznodziejów, [w:] Integralne kształcenie..., dz. cyt., s. 319-333.
54 E. Stateczny, Listy..., dz. cyt., s. 120.
55 E. Stateczny, Listy..., dz. cyt., s. 171. 
z najwspanialszych widoków, kiedy mówca doświadczony weźmie w swoją moc i posiadanie swoich słuchaczy; nie ma smutniejszego zajścia, jak kiedy pomiędzy mówcą i audytorium stoi ściana" ${ }^{56}$. 0 . Stateczny zauważa, że wysiłek związany z kształtowaniem umiejętności krasomówczych powinien człowiek poświęcić na chwałę Boża i pożytek ludzki ${ }^{57}$. Kończy aktualną i dziś prośbą: „Kochaj i pielęgnuj język polski! Weńtchnij swoje koncepcje twórcze o wymowie, a w zawodzie swoim krasomówczym spokojnym być możesz"58.

\section{Podsumowanie}

Niniejszy artykuł stanowi drobny wkład w historię kaznodziejstwa. O. Euzebiusz Stateczny nie był wybitnym teoretykiem głoszenia słowa Bożego, dlatego jego nazwisko nie trafiło na karty opracowań historii kaznodziejstwa w Polsce. Niemniej jednak warto było poddać jego dorobek analizie. Reprezentuje on bowiem sposób myślenia i rozumienia kaznodziejstwa charakterystyczny dla początków XX wieku, kiedy to homiletykę rozumiano jako retorykę kościelną. Brakowało w pełni teologicznego ujmowania zagadnień przepowiadania słowa Bożego. Mniejszą uwagę zwracano na treść, większą na formę kazania ${ }^{59}$. Tak więc rady kaznodziejskie o. Statecznego dotyczą przede wszystkim kwestii formalnych. Aktualność stracił charakterystyczny dla Statecznego i jego epoki sposób nazywania pewnych zjawisk dotyczących mówcy i jego dzieła, jednak pod względem merytorycznym współczesna myśl homiletyczna zawiera wskazania podobne do tych, o których pisał o. Stateczny. I dziś od mówcy oczekuje się intelektualnej, duchowej i społecznej dojrzałości, a od jego dzieła porządku myślowego i jasno określonej struktury.

56 E. Stateczny, Listy..., dz. cyt., s. 104.

${ }_{57}$ Autor dokonuje obrazowego porównania, iż chwała Boża i pożytek ludzki są jak dwa morza, do których powinny spływać krople potu z ludzkiego czoła. E. Stateczny, Listy..., dz. cyt., s. 119.

$58 \quad$ E. Stateczny, Listy..., dz. cyt., s. 173.

59 K. Panuś, Historia kaznodziejstwa, Kraków 2007, s. 393. 


\section{Summary}

\section{Homiletic indications comprised in The letters regarding eloquence}

The letters regarding eloquence (written by father Euzebiusz Franciszek Stateczny) were published in 1920 AD. In this book, its author gathered all instructions which had been issued by him earlier in parts. They were given a form of five letters. Father Stateczny stressed that his work is neither a manual of rhetoric or homiletics nor a proper elaboration of the discussed subject. The book is focused on orator's and his speech's attributes mainly.

The present article depicts person of Euzebiusz Stateczny, introduces reader to his work and ponders on actuality of indications given by the author of The letters...

Keywords: Euzebiusz Franciszek Stateczny OFM, letters, eloquence, homiletics, rhetoric

\section{Wskazania homiletyczne zawarte w Listach o wymowie ojca Euzebiusza Sta- tecznego}

W 1920 roku została wydana książka o. Euzebiusza Franciszka Statecznego Listy o wymowie. Autor zebrał w niej publikowane wcześniej w częściach wskazania dla mówców ujęte w formę pięciu listów. Zaznaczał, że jego dzieło nie ma charakteru podręcznika retoryki czy homiletyki ani nie jest pełnym opracowaniem zagadnienia. Swoją uwagę koncentruje na przymiotach mówcy oraz cechach jego dzieła. Artykuł niniejszy przybliża sylwetkę autora, prezentuje treść jego dzieła i podejmuje próbę odpowiedzi na pytanie o aktualność zawartych w nim wskazówek.

Słowa kluczowe: Euzebiusz Franciszek Stateczny OFM, listy, wymowa, homiletyka, retoryka

\section{Bibliografia}

Bednarek A., Kaznodzieja młodopolski, „Przegląd Homiletyczno-Pastoralny” 3 (1999), s. $128-134$.

Biliński K., Modernista w habicie. Ksiądz Franciszek Euzebiusz Stateczny oraz jego pamiętnik, Wrocław 1998.

Biliński K., Szteinke A. J., Stateczny Franciszek, [w:] Polski słownik biograficzny, t. 42, red. A. Romanowski, Warszawa-Kraków 2003-2004, s. 566-569.

Borowski A., Kaznodzieja jako retor, [w:] Sługa słowa, red. W. Przyczyna, Kraków 1997, s. 180-192.

Helsztyński S., Inferno w klasztorze, [w:] S. Helsztyński, Meteory Młodej Polski, Kraków 1969, s. 63-86.

Korolko M., Podręcznik retoryki homiletycznej, oprac. G. Jaśkiewicz, Kraków 2010. 
Müller K., Homiletyka na trudne czasy, Kraków 2003.

Panuś K., Rola historii kaznodziejstwa w procesie kształcenia kaznodziei, [w:] Integralne kształcenie kaznodziei, red. W. Broński, Lublin 2006, s. 253-261.

Panuś K., Historia kaznodziejstwa, Kraków 2007.

Siwek G., Miejsce retoryki w homiletyce, [w:] Retoryka dziś. Teoria i praktyka, red. R. Przybylska, W. Przyczyna, Kraków 2001, s. 283-300.

Siwek G., Retoryka w procesie kształcenia kaznodziejów, [w:] Integralne kształcenie kaznodziei, red. W. Broński, Lublin 2006, s. 319-333.

Sławiński H., Przyczyna W., Homiletyka a retoryka. Przeszłość, teraźniejszość, przyszłość, „Przegląd Homiletyczny” 9 (2005), s. 133-141.

Sławiński H., Retoryka w przepowiadaniu słowa Bożego - historia i aplikacja na przykładzie homilii Jana Pawła II wygłoszonej we Włocławku 7. 06. 1991 r., [w]: Jan Paweł II apostoł prawdy, red. J. Kędzierski, Włocławek 2005, s. 283-292.

Stateczny Euzebiusz Franciszek, [w:] Słownik polskich teologów katolickich, t. IV, red. H. E. Wyczawski, Warszawa 1983, s. 197-202.

Stateczny Euzebiusz Franciszek, [w:] Słownik polskich pisarzy franciszkańskich (bernardyni i franciszkanie ślascy, franciszkanie konwentualni, klaryski oraz zgromadzenia trzeciej reguły), red. H. E. Wyczawski, Warszawa 1981, s. 457-463.

Stateczny E., Listy o wymowie, „Gazeta Kościelna” (1900) 29, s. 282-285; (1900) 30, s. 293-294; (1900) 31, s. 304-305; wyd. rozszerzone: „Nowa Biblioteka Kaznodziejska” (1913) t. 14, s. 88-100, 173-180, 258-268, 349-356, 446-452, 516-532; (1913/1914) t. 15, s. 93-104, 195-200, 304-308, 434, 436, 523, 618-620; (1914) t. 16, s. 96-100, 171-172, 280-284, 390-396, 492-496, 592-601. Toż samo w wydaniu osobnym: Listy o wymowie, Poznań-Warszawa 1920.

Szteinke A. J., Euzebiusz Franciszek Stateczny OFM (1864-1921) w świetle nowych źródet, „Studia Franciszkańskie” 16 (2006), s. 283-311.

Twardy J., Zachowanie kaznodziei na ambonie, [w:] Mowa żywa. Wybrane aspekty komunikacji kaznodziejskiej. Sympozjum Sekcji Homiletów Polskich. Kielce-Skorzeszyce 2728 X 2003, red. J. Twardy, W. Broński, J. Nowak, s. 167-185.

Warmiński J., Kirchniawy Franciszek ks., [w:] Encyklopediakatolicka, t. 9, red. A. Bednarek i in., Lublin 2002, k. 4. 